\title{
LUPTA CORP LA CORP CU SAU FĂRĂ ARMAMENTUL PORTABIL DIN DOTARE - ELEMENTE FUNDAMENTALE PENTRU INSTRUIREA MILITARULUI MODERN
}

\author{
HAND-TO-HAND COMBAT WITH OR WITHOUT PORTABLE ARMAMENT - \\ FUNDAMENTAL ELEMENTS FOR THE TRAINING \\ OF THE MODERN MILITARY
}

\author{
Lt.col.instr.sup.dr. George-Florin BĂIŢAN*
}

\begin{abstract}
În ciuda progreselor tehnologice, lupta corp la corp cu sau fără armamentul portabil din dotare rămâne o necesitate în mediul de operare contemporan, mai ales având în vedere ambiguitatea războiului urban și interacțiunea strânsă și regulată a militarilor cu diverși adversari (combatanți sau necombatanți) într-un spectru larg al situațiilor în care este utilizată forța. Fiind un angajament între două sau mai multe persoane, într-o confruntare în care nu este folosită muniția, instruirea militarilor privind lupta corp la corp pare o componentă importantă, pe care armata trebuie să o ia în considerare în pregătirea fizică a militarilor pentru viitoarele conflicte. Cultivarea curajului pentru creșterea încrederii în forțele proprii este unul dintre cele mai importante beneficii pe care îl pot avea antrenamentele specifice luptei corp la corp. Într-o situație tensionată, a avea formate deprinderi de luptă în acest sens poate însemna diferența dintre deschiderea focului și escaladarea conflictului, pe de o parte, și evitarea disputelor printr-o abordare bazată pe autostăpânire în fața factorilor care provoacă durere și frică, pe de altă parte.

Despite technological advances, hand-to-hand combat with or without portable armament remains a necessity in the contemporary operating environment, especially given the ambiguity of urban warfare and the close and regular interaction of the military with various adversaries (combatants or non-combatants) a wide range of situations in which force is used. Being a commitment between two or more people, in a confrontation in which ammunition is not used; training the military on hand-to-hand combat seems an important component that the military must consider in the physical preparation of the military for future conflicts. Cultivating courage to increase self-confidence is one of the most important benefits that handto-hand combat training can have. In a tense situation, having trained fighting skills in this regard can mean the difference between opening fire and escalating conflict, on the one hand, and avoiding disputes through a self-control approach to the factors that cause pain and fear, on the other hand.
\end{abstract}

Cuvinte-cheie: lupta corp la corp; armament portabil; procedee tehnice; antrenament specific; pregătire fizică; educație fizică militară.

Keywords: hand-to-hand combat; portable weapons; technical procedures; specific training; physical training; military physical education.

Lupta corp la corp constă într-o confruntare fizică, concomitent între doi sau mai mulți militari, cu mâinile goale sau folosind armamentul portabil (fără a avea muniţie) ori materialele din dotare, cum ar fi: pistolul/pușca mitralieră, pistolul, baioneta, lopata mică de infanterie etc. Formarea deprinderilor motrice la militari în această formă mixtă a artelor marţiale trebuie să fie una dintre componentele fundamentale

\footnotetext{
*Academia Tehnică Militară „Ferdinand I” e-mail: baitan_george_florin@yahoo.com
}

ale modelelor de instruire a militarului modern. Este vorba despre capacitatea unui militar de a se gândi la următoarea sa mișcare, fiind conștient de condițiile sau de modificările ambientale apărute și luând în considerare procedeul pe care ar putea să-1 folosească împotriva adversarului său.

Militarii trebuie să fie pregătiți să utilizeze diferite niveluri de forță, având în vedere faptul că intensitatea unui conflict se poate schimba doar în câteva momente. Multe operații militare (precum, misiunile de menținere a păcii sau cele de evacuare a civililor necombatanți ori a personalului militar neesențial) se vor desfășura utilizând intenționat 
un număr mai redus de armament și de muniție. În aceste situații, dacă apare o confruntare neașteptată, stăpânirea procedeelor de luptă corp la corp cu și fără armamentul portabil din dotare le poate salva viața militarilor, deoarece automatizarea acestor acțiuni motrice ajută și la dezvoltarea curajului și a încrederii în sine. Odată cu formarea acestor deprinderi, vine și înțelegerea agresivității controlate și a capacității de a rămâne concentrat pe timpul unei constrângeri. Programul de antrenament pentru consolidarea deprinderilor de a lupta corp la corp cu un adversar va include și o componentă mai dură, de pregătire fizică specifică, care este, în același timp, atât epuizantă fizic, cât și solicitantă mental. Obiectivele generale ale acestor tipuri de antrenamente trebuie să cuprindă, pe lângă educarea tuturor calităților motrice de bază sau specifice autoapărării, și formarea curajului personal, a încrederii în sine, a autodisciplinei și a „spiritului corpului”".

Instruirea și antrenamentul militarilor pentru a lupta corp la corp, cu sau fără armamentul portabil din dotare se execută în scopul formării deprinderilor de acțiune adaptate specificului situaţiilor care apar în timpul desfășurării luptei, precum și în timpul îndeplinirii unor misiuni de luptă independente, în care nu poate fi folosit focul armamentului individual.

\section{Aspecte generale privind pregătirea specifică pentru lupta corp la corp}

cu sau fără armamentul portabil din dotare

Un studiu realizat recent a constatat că militarii americani care au desfășurat misiuni în teatrele de operații din Irak și Afganistan (între anii 2004 și 2008) au raportat (în proporție de 19\%) faptul că au utilizat cel puțin o dată un procedeu tehnic de luptă corp la corp, într-o varietate de circumstanțe și contexte (în timpul deplasării prizonierilor, controlului mulțimii sau accesului în bază a persoanelor pe la punctul de control etc.). Acest lucru vine în sprijinul cercetărilor anterioare care au indicat faptul că, în ciuda progreselor tehnologice, lupta corp la corp a rămas un aspect persistent al războiului modern².

La baza tuturor tehnicilor de autoapărare, se află câteva elemente esențiale, pe care orice militar trebuie să le aplice pentru a învinge un adversar într-o luptă corp la corp. Învățarea progresivă și în mod sistematic a acestora va insufla militarilor câteva aspecte fundamentale pe care este întemeiată autoapărarea, precum:

- calmul și echilibrul mental - în timpul unei lupte, un militar trebuie să-și păstreze capacitatea de a gândi lucid și nu trebuie să permită fricii sau furiei să-i controleze acțiunile;

- conștientizarea situației - lucrurile care se întâmplă adesea în jurul militarilor care sunt implicați într-o luptă corp la corp ar putea avea un impact direct asupra rezultatului final al luptei. Acest principiu se referă la folosirea în mod eficient a obiectelor existente în preajmă (așa-numitele „arme de oportunitate" $)$ sau la primirea unui posibil ajutor de la ceilalți militari care se alătură luptei;

- tehnica supleţei - un militar nu se poate baza pe presupunerea că este mai mare și mai puternic decât adversarul. Prin urmare, niciodată nu ar trebui să caute să se opună inamicului printr-o încercare directă în forță. Utilizarea forței adversarului prin aplicarea unor tehnici articulare şi a unor eschive realizate prin pivotări poate constitui o modalitate și o strategie de luptă pentru a depăși o forță superioară;

- baza de susținere - se referă la adoptarea unei poziții stabile a corpului, din care să se poată trece rapid în atac sau în apărare (în funcție de situație). În general, un militar trebuie să-și menţină stabilitatea corpului prin coborârea centrului de greutate și mărirea bazei de susținere;

- poziţia dominantă a corpului - se referă la poziționarea corpului militarului luptător, în raport cu cel al adversarului său. Atunci când lupți, înainte de a aplica orice tehnică de scoatere din luptă a adversarului, un principiu vital este acela de a obține și de a menține controlul asupra inamicului prin păstrarea unei poziții corporale dominante (în special în lupta la sol);

- distanţa optimă de luptă - fiecare procedeu tehnic are o distanţă față de adversar, de la care acesta trebuie iniţiat pentru a avea cea mai mare eficiență, ținând cont și de timpul necesar pentru a traversa acest spaţiu, de unghiul și de ritmul atacului ${ }^{4}$. Pentru a controla lupta, militarul luptător trebuie să controleze distanța dintre el și adversar;

- echilibrul fizic - se referă la capacitatea militarului de a-și menține echilibrul și de a rămâne într-o poziție verticală stabilă;

- tehnicile articulare - un militar luptător trebuie să-și folosească părțile corpului pentru 
a-și crea un avantaj, folosind procedee tehnice care vizează blocarea sau răsucirea membrelor adversarului de la nivelul articulaţiilor. Utilizând pârghiile articulare, un militar poate ajunge într-o poziție dominantă faţă de un inamic cu o greutate corporală mult mai mare.

Un program de pregătire specifică pentru lupta corp la corp cu sau fără armamentul portabil din dotare trebuie conceput special pentru a putea antrena cât mai mulți militari, pentru a deveni luptători eficienți în cel mai scurt timp posibil și într-un mod cât mai sigur. În acest sens, trebuie luate câteva măsuri și precauții generale de siguranță:

- procedeele tehnice de luptă ar trebui să fie învăţate și consolidate într-o anumită ordine, asimilate progresiv, de la simplu la complex, iar cele considerate mai periculoase (precum și combinațiile) ar trebui instruite, după ce militarii s-au familiarizat cu dinamica tehnicilor generale. Acest lucru va avea, ca rezultat, mai puţine leziuni grave, cauzate de mișcările mai dinamice;

- instruirea militarilor trebuie să se desfãșoare întotdeauna sub supravegherea adecvată a unui instructor calificat, deoarece procedeele tehnice implicate prezintă un potențial periculos;

- majoritatea antrenamentelor trebuie efectuate pe o suprafață de luptă moale (precum o zonă cu iarbă sau cu nisip), reducând astfel stresul asupra articulațiilor membrelor inferioare (precum gleznele și genunchii);

- strangulările (sufocarea prin sugrumare) sunt cel mai bun mod de a pune capăt unei lupte și cel mai eficient mod pentru a imobiliza un adversar în doar câteva secunde. Aceste procedee sunt suficient de sigure pentru a le aplica la antrenamente exact ca pe câmpul de luptă;

- luxațiile articulare - pentru a scoate din luptă un inamic, atacurile trebuie îndreptate împotriva articulațiilor mai mari (cum ar fi cotul sau umărul). Aceste încheieturi sunt foarte dureroase cu mult înainte de a se produce vătămarea lor, fapt care le permite militarilor să se antreneze, exersând procedeele tehnice, în condiții foarte apropiate de cele reale, fără a exista un risc semnificativ de rănire. Excepțiile sunt atacurile asupra încheieturii mâinii (care se lezează foarte ușor) și asupra genunchiului (răsucirea acestuia devenind dureroasă,în momentul în care s-ar putea să fie prea târziu). Prin urmare, aceste atacuri ar trebui învăţate cu mare atenție și nu ar trebui să fie permise în competițiile sportive, ci, mai degrabă, utilizate doar într-o confruntare reală cu un inamic;

- loviturile sunt acele atacuri puternice și eficiente, executate asupra inamicului cu o parte a corpului sau cu armamentul portabil din dotare, în scopul nimicirii lui și capturării armamentului său. Acestea sunt o parte importantă a unei strategii generale de luptă și pot fi foarte eficiente într-o confruntare, deoarece, de cele mai multe ori, pune adversarul într-o situație nefavorabilă. În cadrul antrenamentelor, loviturile pot fi practicate folosind diverse echipamente de protecție (căști, bustiere, tibiere, veste, protecții dentare/genitale etc.), pentru a asigura prevenirea accidentărilor grave. Instruirea militarilor ar trebui să se concentreze continuu asupra situațiilor care pot apărea într-o luptă reală.

Instruirea profesională este cheia succesului în formarea deprinderilor militarilor de a lupta corp la corp cu sau fără armamentul portabil din dotare. Instructorii/profesorii de educație fizică militară trebuie să fie pregătiţi din punct de vedere fizic și extrem de pricepuţi în demonstrarea și punerea în practică a elementelor tehnice. Încrederea, entuziasmul și evaluarea competențelor tehnice sunt esenţiale pentru a avea succes în predarea tehnicilor luptei corp la corp. Asistenții instructorului militar (instructori sportivi sau militari desemnaţi de acesta pentru a-l ajuta în procesul instructiv-educativ) trebuie, de asemenea, să fie instruiţi corespunzător pentru a participa la supravegherea și demonstrarea procedeelor tehnice. Având în vedere aceste aspecte, selectarea instructorilor sportivi este un prim pas în stabilirea unui program de antrenament eficient.

Pentru a perfecționa diferitele tehnici de luptă corp la corp, este necesară depunerea unui efort neîntrerupt, pentru a ajunge la aplicarea instinctivă a mișcărilor și pentru a învăța și pe alții cum să le execute în siguranță. Următoarele responsabilități ale instructorilor/profesorilor de educație fizică militară constituie nucleul planificării și executării instruirii, pentru formarea deprinderilor de a lupta corp la corp cu sau fără armamentul portabil din dotares:

- să realizeze o eficiență maximă cu un efort minim, depunând o muncă neîntreruptă pentru a reduce explicațiile, mișcările și activitățile inutile. Antrenamentul trebuie simplificat, fără a compromite conținutul, eficiența sau siguranța lui; 
- să crească nivelul de măiestrie sportivă prin dezvoltarea mobilităţii și supleței, precum și prin controlul și gestionarea stresului;

- să consolideze detaliile fiecărei tehnici și să ofere un feedback constructiv (justificat și ancorat într-un anumit context), folosind un umor ocazional pentru a motiva militarii, dar evitând denigrarea sau jignirea lor;

- să se asigure că materialele folosite pentru instruire sunt prezente în cantităţi suficiente pentru toți militarii, că zonele de antrenament sunt bine întreținute și că nu există pericole de accidentare;

- să se pregătească teoretic și practic înainte de toate sesiunile de antrenament, desfășurând ședințe de instruire de cel puțin patru ore pe săptămână, pentru a menține un nivel înalt de calificare;

- să pregătească din rândul militarilor câte un instructor sportiv competent (pentru fiecare subunitate de nivel pluton) și să încurajeze instruirea lor inclusiv în afara orelor de program;

- să îmbunătățească performanțele militarilor, oferind direcții clare de lucru;

- să solicite tuturor militarilor să respecte o disciplină strictă.

Siguranța militarilor trebuie să fie principala preocupare a instructorului/profesorului de educaţie fizică militară și a asistenților săi. În acest sens, cele mai bune măsuri de siguranță sunt o verificare și o supraveghere constantă. Pentru a preveni rănirea militarilor, instructorul/profesorul de educație fizică militară trebuie să ia în considerare și să prelucreze, pentru toți militarii, următoarele măsuri de siguranță, înainte de desfășurarea unui antrenament specific luptei corp la corp cu sau fără armamentul portabil din dotare, după cum urmează:

- toate ședințele practice de pregătire trebuie supravegheate îndeaproape și în mod constant. $N u$ lăsați niciodată un grup nesupravegheat!;

- deprinderea sistematică a militarilor cu fiecare procedeu printr-o explicaţie și o demonstrație completă, înainte ca aceștia să încerce mișcările;

- Nu permiteți militarilor să-și depășească atribuțiile sau să încalce instrucțiunile primite!;

- în timpul etapelor de învățare sau de perfecționare a unor combinații de procedee tehnice, partenerul de antrenament nu trebuie să opună rezistență, pentru a permite asimilarea corectă a acestora de către cel care exersează;
- asigurarea unui spaţiu adecvat între militari pe timpul tuturor lucrărilor practice (se recomandă cel puțin $9 \mathrm{~m}^{2}$, pentru fiecare pereche de militari);

- verificarea militarilor privind golirea buzunarelor, scoaterea tuturor bijuteriilor și a semnului personal de identitate $^{6}$, înainte de începerea antrenamentului;

- loviturile în punctele vitale (cum ar fi: capul, gâtul sau zona inghinală) trebuie doar simulate, nu executate. Militarii pot folosi lovituri ușoare asupra altor zone vulnerabile (cum ar fi zona abdominală), dar trebuie să fie prudenți în orice moment al execuției;

- militarii trebuie să cunoască maniera în care se execută atingerile fizice și care sunt semnalele verbale pentru a indica partenerului când trebuie să se oprească din execuția anumitor procedee tehnice de luptă (strangulări, luxări, fixări etc.);

- militarii trebuie să efectueze programul de încălzire și exercițiile de stretching la începutul ședinţelor practice;

- învăţarea și exersarea căderilor se va face înainte de a efectua proiectările sau secerările;

- pentru a evita apariţia leziunilor, militarul care urmează să fie dezarmat nu trebuie să țină degetul în interiorul gărzii trăgaciului;

- când se exersează procedeele de dezarmare a adversarului care atacă cu baioneta, militarii trebuie să o țină în teacă (indiferent dacă aceasta este sau nu montată la armă) sau să se folosească baionete din cauciuc;

- suprafața pe care se execută antrenamentele trebuie să aibă o zonă tampon de siguranță, de minimum 3 metri față de pereții sau obiectele din jur, în special la antrenamentele care presupun aruncări sau luptă la sol. Aceasta trebuie inspectată pentru a înlătura eventualele obiecte străine, care ar putea provoca răniri;

- punerea și scoaterea baionetei se execută doar la comanda conducătorului activitătii;

- armamentul și materialele ar trebui să fie așezate pe sol, atunci când militarilor li se oferă explicații sau demonstrații;

- zona de antrenament ar trebui să fie o suprafață plană care să nu devină alunecoasă, atunci când este udă;

- militarii stângaci ar trebui să fie puși să lucreze între ei, pentru a preveni apariţia unor vătămări corporale, atunci când se execută anumite mișcări complexe; 
- atunci când vremea este nefavorabilă, mănuşile ar trebui să fie purtate obligatoriu la ținuta combat de antrenament.

Un avantaj al antrenamentelor specifice luptei corp la corp cu sau fără armamentul portabil din dotare este că acestea pot fi efectuate aproape oriunde, cu puțină pregătire a zonei de antrenament. Un teren plat cu iarbă, în aer liber, fără obstacole pe el, este potrivit pentru aceste ședințe de pregătire. Instructorii vor folosi, ca formații de lucru, perechile de doi militari, stabilite în funcție de înălțimea și greutatea lor, care se vor poziţiona față în față și care vor păstra o distanță minimă de 3 metri față de celelalte grupuri.

Procedeele de asalt la baionetă oferă comandantului o oportunitate unică de antrenament, permițând militarilor să-și pună în practică deprinderile motrice de mânuire a armamentului portabil din dotare, în condițiile unei lupte simulate. Pentru a spori realismul, se recomandă crearea unei atmosfere de luptă prin folosirea unor efecte pirotehnice și prin simularea reală a zgomotelor războiului. Obiectivele de instruire ale procedeelor de asalt cu baioneta includ:

- consolidarea/perfecţionarea deprinderilor de luptă corp la corp cu sau fără armamentul portabil din dotare;

- dezvoltarea capacităţii de acțiune, în condiții complexe de efort, cu aplicarea de procedee și contraprocedee specifice atacului și autoapărării;

- creșterea nivelului de pregătire fizică a militarilor, ca urmare a executării cu agresivitate a procedeelor tehnice;

- dezvoltarea forței, vitezei, coordonării și preciziei;

- desfãşurarea unor confruntări fizice realiste, în condiții asemănătoare celor întâlnite pe un câmp de luptă, folosind armamentul portabil din dotare;

- dezvoltarea voinței și creșterea rezistenței psihice a militarilor, aspecte necesare într-o luptă corp la corp;

- oferirea unor oportunități, pentru comandanţii de subunități, de a-și dezvolta propriul sistem de comandă, conducere și control.

Înainte de începerea unui antrenament, militarii trebuie să fie pregătiți pentru solicitare fizică. În acest sens, executarea unui program de încălzire va crește treptat ritmul cardiac și temperatura internă a corpului, iar stretchingul va pregăti ligamentele și tendoanele pentru antrenament, scăzând astfel șansele de accidentare. După această încălzire inițială, simularea mișcărilor din cadrul procedeelor tehnice ale luptei corp la corp poate fi folosită pentru a continua și a diversifica încălzirea. Acest lucru permite utilizarea la maximum a timpului de antrenament, combinând o parte a încălzirii cu formarea memoriei musculare și perfecționarea tehnicilor de bază.

O demonstrație a tehnicilor de luptă corp la corp bine executată de către un profesor/instructor profesionist în domeniu este un lucru crucial pentru ca militarii să aibă succes în activitatea de învățare, iar mișcările prezentate într-un mod neconvingător pot distruge imediat credibilitatea instruirii. În acest sens, pentru a fi eficientă, ținând cont de mărimea subunității care urmează să fie instruită, „demonstrația trebuie realizată la nivel de model fie de către specialist (se mai numeşte şi demonstraţie nemijlocită ${ }^{7}$ ), fie de către un alt militar din grupul de instruit, a cărui pregătire tehnică îi permite acest lucru (poartă numele şi de demonstraţie mijlocită $\left.{ }^{8}\right)^{\prime \prime}$.

Pentru a arăta și a explica un anumit procedeu, instructorii/profesorii de educaţie fizică militară trebuie să utilizeze o demonstrație secvenţială, împărţind execuţia tehnică în mai mulţi pași, astfel încât militarii să poată vedea clar cum se realizează mișcarea, de la început până la sfârșit. Executarea secvențială oferă militarilor o modalitate de a observa mecanica fiecărui procedeu tehnic în parte. Această metodă de predare permite instructorului să explice în detaliu care este succesiunea mișcărilor, în timp ce asistenții instructorului se pot mișca liber la fața locului printre militarii care exersează, intervenind (dacă este necesar) pentru corectarea greșelilor de execuţie.

Când instructorul devine încrezător în faptul că militarii care sunt instruiţi au devenit pricepuți în executarea secvențială a unui procedeu tehnic, trebuie să treacă la efectuarea integrală a acestuia. Crescând treptat viteza de execuție până la cea folosită în luptă (care nu înseamnă întotdeauna foarte repede), militarii vor sesiza cât de eficient este fiecare procedeu tehnic în parte. Acest lucru va produce un sentiment de siguranță, care le va permite să dezvolte o imagine mentală clară asupra principiilor din spatele tehnicii și le va conferi încredere în capacitatea lor de a aplica procedeele tehnice în timpul unei confruntări reale. 
Pernele de antrenament și echipamentul de protecție individuală (cască, vestă, tibiere etc.) sunt recomandate pentru a fi folosite în antrenamente, deoarece acestea îi protejează pe partenerii de antrenament, chiar și atunci când loviturile sunt executate cu forță maximă. $\mathrm{Cu}$ toate că loviturile sunt o parte foarte importantă a unei lupte corp la corp, ele nu sunt cel mai eficient mod de a termina o luptă. În antrenamente, instructorii ar trebui să încurajeze spiritul agresiv al militarilor, pentru ca aceștia să simtă eficacitatea tehnicilor de lovire și să-și dezvolte forța de lovire.

În timpul desfășurării unui antrenament de luptă corp la corp, conducătorii activităţii trebuie să menţină controlul pe tot parcursul ei. Este foarte uşor, pentru un militar indisciplinat, să treacă dincolo de limitele regulamentare impuse, mai ales atunci când acesta devine frustrat de slaba lui pregătire. De aceea este recomandat ca acesta să știe ce se așteaptă de la el și care sunt repercusiunile, în cazul comiterii unor acțiuni inadecvate. În acest sens, cea mai importantă măsură de control pe care o poate avea un conducător de activitate, după începerea programului de instruire, este un mijloc de a opri acțiunea (acest lucru poate fi un simplu fluier, ale cărui semnale sonore trebuie să fie clare și ușor de auzit de către toți militarii).

\section{Tehnicile de bază ale luptei corp la corp cu și fără armamentul portabil din dotare}

Tehnicile de bază ale luptei corp la corp cu și fără armamentul portabil din dotare pot fi clasificate în următoarele cinci mari categorii: lupta la sol, ducerea la sol, lovirea, mânuirea armamentului și controlul poziției dominante.

Tehnicile de bază ale luptei la sol sunt construite pe o înţelegere fundamentală a poziției corporale dominante, care ar trebui să fie obiectivul principal al majorității antrenamentelor specifice, înainte de a trece la tehnicile mai dificile din poziția stând. La sol este locul în care tehnica poate fi cel mai uşor folosită, neținând cont prea mult de dimensiunea și de puterea adversarului.

Înainte de a aplica orice tehnică de dezarmare sau de ucidere, militarul trebuie, mai întâi, să câștige și să mențină o poziție corporală dominantă, fapt care îi va permite să învingă și un adversar mai puternic decât el. Pentru a deveni un luptător competent, este fundamental să apreciezi permanent care este această poziție dominantă în luptă, deoarece ea depinde de numeroasele procedee tehnice de luptă existente în artele marțiale. Dacă o tehnică decisivă de atac este efectuată dintr-o poziție dominantă și eșuează, militarul o poate încerca pur și simplu din nou, iar dacă aceasta este executată din altă poziție decât cea dominantă și eșuează, de obicei acest lucru va însemna înfrângere.

Pozițiile corporale dominante vor fi învățate/ consolidate/perfecționate la sol, în ordine și în funcție de prioritate, acestea fiind întâlnite în procedeele tehnice de imobilizare (fixare) și de strangulare, cele mai utilizate în artele marțiale. Pentru a înțelege mai bine aceste procedee, în această etapă sunt însușite și modalităţile de ieșire dintr-o imobilizare sau dintr-o strangulare, precum și mișcările care duc la finalizarea luptei (lovituri repetate în zone vitale, luxarea articulațiilor etc.). După ce militarii au aprofundat elementele de bază ale luptei la sol, se vor preda sistematic și alte tehnici complexe de luptă la sol (posibile combinații și înlănțuiri cu alte procedee cunoscute), importante în formarea unor luptători competenţi.

Înainte de a învăța tehnicile de ducere $a$ adversarului la sol, militarii trebuie să cunoască câteva reguli de bază pentru a anihila șocul provocat de contactul corpului cu pământul, pentru a avea ,o cădere inteligentă" (impactul cu solul să fie redus la maximum). Fiecare cădere care este repetată (înainte, înapoi, lateral - stânga/dreapta) reprezintă o oportunitate pentru partenerul de antrenament, de a-și perfecționa diverse procedee de ducere la sol. Aceste elemente trebuie ,reîmprospătate" mereu înainte de antrenament, lucru realizat cu ușurință prin introducerea lor în secvența de pregătire a organismului pentru efort.

Pentru a deține controlul unei lupte, trebuie să controlezi distanța dintre tine și adversar, acesta fiind mult mai periculos, atunci când se află la distanţă. De aceea scopul într-o confruntare este de a evita acest interval, iar când te antrenezi, obiectivul principal ar trebui să fie insuflarea curajului de a reduce această distanță pentru a lua o priză convenabilă sau pentru a-l lovi pe adversar. Majoritatea modalităţilor de ducere la sol presupun realizarea unor prize pe adversar, acestea fiind incluse în tehnicile de luptă competiţionale din diverse stiluri ale artelor marțiale, dar într-o luptă reală, toate acestea nu cunosc limite (aruncări, secerări, răsturnări etc.). Dacă se întâmpină dificultăți în a obține controlul asupra inamicului, 
o tehnică bună este aceea de a-l împinge, mai întâi, cu spatele într-un perete.

De cele mai multe ori, loviturile de braț sau de picior nu reprezintă o metodă eficientă de a pune capăt rapid unei lupte (cu excepția celor aplicate în punctele vulnerabile ale corpului). $\mathrm{Cu}$ toate acestea, ele sunt întâlnite în majoritatea luptelor corp la corp, iar militarii trebuie să cunoască și să stăpânească distanţa optimă față de adversar (,se referă la apropierea necesară pentru cea mai eficace utilizare a unei tehnici, executată la unghiul corect de impact cu suprafaţa vizată") ${ }^{10}$. Este important de reținut faptul că, în timp ce te găsești în raza de acțiune a adversarului, ești predispus la un contraatac din partea acestuia.

Cheia dezvoltării unor abilități eficiente de lovire este înțelegerea distanței optime care se recomandă a fi luată față de un adversar, cunoașterea tehnicilor eficiente, în funcție de această distanță, şi controlul tranziţiei dintre diverse intervale. Procedeele tehnice vor fi predate individual, chiar dacă aproape niciodată nu vor fi folosite în acest fel. Ele trebuie abordate ca o parte dintrun ansamblu (cum se încadrează într-o strategie generală de luptă), ținându-se cont de faptul că o lovire eficientă nu este ceva ce poate fi predat/ învăţat peste noapte.

Loviturile de braț (cu pumnul sau cu cotul) trebuie efectuate în combinații pentru a fi eficiente și trebuie exersate pentru a deveni automatisme, mai ales în condiţiile stresului unei lupte. O atenție deosebită ar trebui să fie acordată retragerii brațului după fiecare lovitură executată, ajungând întotdeauna într-o postură defensivă, deoarece adversarul poate contracara în orice moment. În timpul unei lupte corp la corp, loviturile de picior cele mai simple și eficiente sunt cele joase, întrucât militarii sunt, de obicei, împovărați cu bocanci și echipamentdeluptă. Gradele demobilitatearticulară și de flexibilitate musculară ale militarilor sunt, de obicei, scăzute în timpul unei lupte corp la corp cu un adversar, fiind supuse unui stres suplimentar ridicat. De aceea aceștia trebuie să se bazeze pe abilitățile motorii brute și pe loviturile care nu necesită mișcări complicate sau mult antrenament pentru învățarea lor.

Mânuirea eficace a armelor portabile din dotare poate oferi un avantaj semnificativ în timpul unei lupte. Pentru ca militarii să fie bine instruiți în utilizarea lor, trebuie să existe o conectivitate între consolidarea procedeelor tehnice ale luptelor armate și ale celor neînarmate. Pe măsură ce militarii vor progresa în programul de instruire, procedeele tehnice de luptă cu armamentul portabil din dotare trebuie să fuzioneze cu celelalte elemente tehnice ale luptei corp la corp învățate, producând un luptător capabil să execute o întreagă gamă de combinați tehnice și tactice.

În majoritatea situațiilor de luptă, armamentul individual din dotare și grenadele de mână sunt singurele arme pe care le are la îndemână un militar. In orice caz, în unele scenarii, militarii trebuie să se lupte cu inamicul în zone înguste (tranșee), în spații închise (încăperile clădirilor) sau în locuri în care sunt prezenți şi necombatanţi. În aceste situații, când rămâi fără muniție sau nu mai ai timp să reîncarci armamentul, baioneta poate fi arma ideală pentru a-1 surprinde pe inamic. Militarii trebuie să folosească imediat și instinctiv procedee tehnice adecvate, în funcție de situație și de armele avute la îndemână.

Principiile folosite în lupta corp la corp cu armamentul portabil din dotare (de obicei, pistolul mitralieră cu baioneta-pumnal montată) sunt asemănătoare cu principiile de luptă cu cuțitul, folosindu-se aceleași unghiuri de atac și mișcări similare ale corpului. Principiile de sincronizare și de distanţă rămân primordiale, principala diferență fiind distanța mai mare, asigurată de lungimea armei. Este necesar ca militarul să lupte corp la corp cu armamentul portabil din dotare folosind biomecanica întregului său corp (nu doar trenul superior), întâlnită la toate procedeele tehnice însușite și să-și dezvolte atitudinea mentală că va supraviețui luptei. Acesta trebuie să evalueze permanent fiecare moment dintr-o luptă pentru a determina care îi sunt opțiunile și avantajele/ dezavantajele față de adversar.

Chiar dacă echipamentele vor fi mereu îmbunătătite, iar tacticile de luptă vor fi permanent revizuite, doar puterea de foc nu va putea să anihileze întotdeauna inamicul. Adesea, el va rămâne în locul său amenajat pentru apărare, până când va fi determinat să se angreneze, prin forța împrejurărilor, într-o luptă de aproape, corp la corp. Rolul militarului, în special în faza finală a asaltului rămâne relativ neschimbat. Misiunea sa este de a se apropia de poziția inamicului și de a-l scoate din luptă, acesta fiind și scopul final al oricărui antrenament individual. Mânuirea armamentului 
portabil din dotare în timpul luptei corp la corp este unul dintre mijloacele finale în acţiunea întreprinsă într-un asalt, pentru a învinge un adversar.

Baioneta este o armă albă de care dispune orice militar, fiind silențioasă și recomandată a se folosi în timpul misiunilor de infiltrare pe timp de noapte, când trebuie păstrată liniștea, sau atunci când situația nu permite încărcarea ori reîncărcarea pistolului (lipsa muniției sau blocarea armei). În ciuda limitărilor, baioneta are și multe alte întrebuinţări utilitare nonluptătoare (sondarea minelor, tăiatul vegetației sau a sârmelor etc.), reprezentând și un mijloc de antrenament pentru ridicarea moralului combatanților și creșterea agresivității luptătorilor.

Pentru a deveni un bun luptător cu armamentul portabil din dotare, un militar trebuie să fie într-o foarte bună formă fizică și mentală. Un program de antrenament fizic bine conceput va spori șansele militarilor de a supraviețui într-o luptă corp la corp cu un adversar. Îmbunătățirea vigilenței mentale va crește posibilitatea de a detecta rapid și de a respinge atacul unui adversar, indiferent din ce direcție vine el. Trăsături, precum agresivitatea, precizia, echilibrul și viteza sunt esențiale atât în antrenamente, cât și în situațiile reale de luptă. Ele vor dezvolta încrederea, coordonarea, forța și rezistența militarilor, calităţi pe care trebuie să le aibă un luptător cu armamentul portabil din dotare. Procedeele tehnice de luptă corp la corp pot suferi ușoare modificări tehnice, în funcție de particularitățile morfofuncționale ale organismului uman, atât timp cât acestea devin mai eficiente.

Baioneta (ținută în mână sau montată la armă) este o armă eficientă, dacă este folosită agresiv, orice ezitare în mânuirea ei putând însemna moartea. Militarul trebuie să atace într-un asalt neîncetat adversarul, până când acesta este eliminat sau dezarmat și capturat. În același timp, trebuie să fie atent pentru a profita de orice zonă a corpului adversarului rămasă descoperită. Dacă nu există astfel de zone, militarul trebuie să-și creeze una prin utilizarea procedeelor de contraatac, respectând următoarele principii:

- atacul trebuie făcut asupra punctelor vulnerabile ale corpului (fața, gâtul, pieptul, abdomenul sau zona inghinală);

- atât în ședințele de antrenament, cât și într-o luptă reală, militarul care utilizează o armă cu baionetă trebuie să folosească un strigăt de luptă agresiv. Acesta va insufla un sentiment de încredere în capacitățile proprii și va provoca intimidarea adversarului;

- deprinderea de a lupta instinctiv, folosind o armă cu baionetă este formată pentru a valorifica agilitatea și tehnica combativă a militarului (mișcările învățate nu trebuie să reprezinte un factor de stres în timpul antrenamentelor).

Lupta corp la corp cu armamentul portabil din dotare se învață în următoarea succesiune: pozițiile de atac (în gardă) și de relaxare (de repaus), deplasările (pasul înainte/înapoi, săritura înainte/înapoi), întoarcerile (schimbarea frontului), împungerile, loviturile, parările și dezarmările; iar pe măsura însușirii procedeelor, acestea se vor combina în exerciții complexe ${ }^{11}$.

Pentru a supraviețui în luptă, militarii trebuie să poată face față oricărei situații neprevăzute. Abilitatea de a folosi orice obiect din apropiere pentru a fi transformat într-o armă, într-o situaţie de viață și de moarte, este limitată doar de ingeniozitatea și de inventivitatea militarilor. Următoarele materiale care sunt accesibile majorității militarilor pot deveni arme pentru atac, contraatac sau apărare împotriva unui adversar: lopata mică de infanterie, casca kevlar, antene radio, pixuri/creioane, diverse frânghii, bastoane, pietre, nisip sau lichide aruncate în ochii duşmanului etc.

Un militar nu se poate baza pe faptul că fiecare confruntare fizică cu un adversar o va începe dintr-o poziţie dominantă. De aceea, pentru a supraviețui, acesta trebuie să stăpânească tehnicile elementare de ieșire dintr-o poziție deficitară, urmată de preluarea controlului asupra planului său de luptă. Când un militar neînarmat se confruntă cu un adversar înarmat cu un cuțit, el trebuie să fie pregătit mental pentru faptul că există probabilitatea de a fi tăiat grav, aceasta fiind mai mică, dacă luptătorul este bine instruit în apărarea împotriva atacurilor cu cuțitul.

Majoritatea confruntărilor corp la corp pe câmpul de luptă vor implica mai mulți combatanți și, indiferent dacă există mai mulți camarazi sau duşmani, ori indiferent dacă unele părți sunt sau nu înarmate, militarii ar trebui să se lupte după un plan bine consolidat și după o strategie de luptă generală. Adevărul fundamental al luptei corp la corp este acela că întotdeauna câștigător va fi cel ai cărui camarazi apar primii cu o armă. Având în vedere echipamentele moderne apărute și complicatele scenarii tactice (și ținând cont de cele două secunde 
disponibile pentru a lua decizii de viață și de moarte), militarii trebuie să fie permanent înarmați cu soluții practice și viabile.

Cea mai frecventă greșeală, atunci când lupți și faci parte dintr-o echipă, este aceea de a intra într-o confruntare fără a avea conceput un plan tactic. Lipsa acestuia va avea ca rezultat executarea unor acțiuni necoordonate și adesea lucrul în echipă va eșua. Doar prin practică se va oferi militarilor încrederea necesară (în ei înșiși și în colegii lor) și se va dezvolta abilitatea de a gândi și de a acționa împreună, în condițiile de stres din timpul unei lupte corp la corp cu adversarii.

\section{Concluzii}

Pentru a-și îndeplini obiectivele, ședințele de antrenament specifice luptei corp la corp cu sau fără armamentul portabil din dotare trebuie incluse într-un program complex de pregătire. Alegerea adecvată și punerea în practică a procedeelor tehnice însușite trebuie să fie instinctuale, ceea ce nu poate fi realizat decât prin integrarea luptei corp la corp în cadrul unui scenariu. Procesul de elaborare a scenariului este unul greu și dificil, militarii trebuind să fie conștienți de faptul că războiul este dur, iar realitatea instruirii pentru război este la fel de dură.

Pregătirea militarilor în utilizarea adecvată a procedeelor tehnice de luptă corp la corp presupune planificarea detaliată a ședințelor de antrenament de către un specialist în educație fizică militară, deoarece riscul de producere a accidentelor trebuie să fie atenuat, controlând atât scenariul, cât și desfășurarea exercițiului în sine. Atunci când se planifică un scenariu care include și lupta corp la corp cu sau fără armamentul portabil din dotare, trebuie luați în calcul mai mulți factori. Un scenariu detaliat și bine gândit le va spune militarilor ce tip de procedee tehnice sunt mai potrivite, în funcție de misiunea care trebuie îndeplinită. Acesta trebuie explicat militarilor în detaliu (evenimentele care conduc până la scenariu, precum și situația tactică imediată), astfel încât acțiunile motrice adecvate să vină în mod natural de la ei, respectând regulile de angajare, care le oferă militarilor înțelegerea clară a actiunilor adecvate.

Fiecare militar ar trebui să dețină cunoștinţe teoretice și deprinderi motrice privind procedeele tehnice de luptă corp la corp cu sau fără armamentul portabil din dotare, deoarece o situație se poate schimba într-o fracțiune de secundă. Lupta corp la corp este întâlnită frecvent în operațiile militare contemporane, fapt ce justifică prioritatea, în formarea militarilor, a acestor deprinderi. Acestea vor fi utilizate într-o varietate de medii tactice, oferind un exemplu excelent al necesității adaptabilității militarilor în războiul modern.

\section{NOTE:}

1 În artele marțiale corpul și spiritul nu sunt considerate niciodată ca fiind separate, ci sunt privite ca două elemente de nedespărțit în desăvârșirea Kai Chi Do (meditaţia mișcării).

2 Peter R. Jensen, Hand-to-Hand Combat and the Use of Combatives Skills: An Analysis of United States Army Post-Combat Surveys from 2004-2008, Center for Enhanced Performance, United States Military Academy, 2014, p. 85.

3 https://urbansurvivalsite.com/weapons-of-opportunit y-use-everyday-objects-self-defense, accesat la 08.03.2021.

4 D. Masciotra, E. Ackermann \& WM. Roth, "«Maai»: The Art of Distancing in Karate-Do Mutual Attunement in Close Encounters", Journal of Adult Development no. 8 / 2001, pp. 119-132.

5 [Headquarters, Department of the Army], Combatives, Field Manual No. FM 3-25.150, Washington DC, 2009, p. 21. $6 \mathrm{https}$ ://lege5.ro/gratuit/gmztkojsgy/semnul-personalde-identitate-regulament? $d p=$ gyzteojrgq 4 do, accesat la 12.03.2021.

7 Atunci când subunitatea este de dimensiunea unui pluton sau mai mică.

8 Atunci când subunitatea este de dimensiunea unei companii sau mai mare.

9 G.C. Ciapa, „Principii și metode de instruire în educația fizică militară”, Buletinul Universităţii Naţionale de Apărare „,Carol I” nr. 3/2019, București, p. 80.

$10 \mathrm{https}$ //frkt.ro/resurse/arbitru-de-karate-shotokan-ku mite-rules, accesat la 29.03.2021.

$11 * * *$ Regulamentul educaţiei fizice militare, Editura Centrul Tehnic-Editorial al Armatei, Bucureşti, 2013, art. 57.

\section{BIBLIOGRAFIE}

*** Regulamentul educaţiei fizice militare, Editura Centrul tehnic-editorial al armatei, Bucureşti, 2013.

[Headquarters, Department of the Army], Combatives, Field Manual No. FM 3-25.150, Washington DC, 2009.

Andrei I., Importanța pregătirii fizice în procesul de instruire militară, Editura Universității Naţionale de Apărare „Carol I”, București, 2015.

Băițan G.F., Pregătirea fizică a militarilor din Armata României în contextul integrării în NATO, Editura Universităţii Naţionale de Apărare „Carol I”, Bucureşti, 2019. 
Ciapa G.C., Pregătirea fizică a militarilor din Armata României în conflictele moderne, Editura Universității Naționale de Apărare „Carol I”, Sta București, 2018.

Ciapa G.C., „Principii și metode de instruire în educația fizică militară”, Buletinul Universităţii Naţionale de Apărare ,, Carol I” nr. 3/2019, București.

Dougherty M.J., Ghidul forțelor speciale neînarmate pentru lupta corp la corp, Tehnici de luptă corp la corp de la cele mai bune unități militare din lume, Editura MAST, 2014.

Jensen Peter R. \& Wrisberg C. A., "Performance under acute stress: A qualitative study of soldiers' experiences of hand-to-hand combat", International Journal of Stress Management, 21, 2014.
Jensen Peter R., Hand-to-Hand Combat and the Use of Combatives Skills: An Analysis of United States Army Post-Combat Surveys from 2004-2008, Center for Enhanced Performance, United States Military Academy, 2014.

Masciotra D., Ackermann E. \& Roth WM., "«Maai»: The Art of Distancing in Karate-Do Mutual Attunement in Close Encounters", Journal of Adult Development no. 8 / 2001.

Larsen M., Modern army combatives: battleproven techniques and training methods, El Segundo, CA: Cruz Bay Publishing, 2013.

https://lege5.ro/gratuit/gmztkojsgy/semnulpersonal-de-identitate-regulament?dp= gyzteojrgq4do https://frkt.ro/resurse/arbitru-de-karateshotokan-kumite-rules 